Check for updates

Cite this: RSC Adv., 2017, 7, 47990

\title{
Ionic liquids as efficient pretreatment solvents for lignocellulosic biomass
}

\author{
Fu-Ling Wang, (D) a Shuang Li, ${ }^{a}$ Yi-Xin Sun, ${ }^{a}$ Hui-Ying Han, ${ }^{a}$ Bi-Xian Zhang, ${ }^{b}$ \\ Bao-Zhong Hu, ${ }^{* c}$ Yun-Fei Gao ${ }^{b}$ and Xiao-Mei Hu*a
}

Ionic liquid (IL)-assisted pretreatment of lignocellulosic biomass has been extensively studied. Cellulose and hemicelluloses are rich resources of sugars for biofuels. Lignin is a valuable feedstock for aromatic-based platform chemicals. In this study, a series of ionic liquids (ILS) were prepared with one-step synthesis and were investigated for their activity to pretreat lignocelluloses. High yields of lignin $(61.0 \%$ and $60.4 \%)$ were achieved through $[\mathrm{Hpy}] \mathrm{Cl}$ and $[\mathrm{Hmim}] \mathrm{Cl}$ pretreatment of poplar. Lignin yields of $51.7 \%$ and $50.3 \%$ were obtained with a $[\mathrm{Hpy}] \mathrm{Cl}$ and $[\mathrm{Hnmp}] \mathrm{Cl}$ pretreatment of bamboo. Improving enzymatic hydrolysis was observed from the regenerated poplar with $[\mathrm{Hpy}] \mathrm{Cl}$ pretreatment and the regenerated bamboo with [Hmim] Cl pretreatment. The isolated fractions were characterized by FTIR (Fourier transform infrared) spectroscopy. SEM (Scanning electron microscopy) and XRD (X-ray diffractometry) were employed to examine the cellulose-rich materials. A 2D ${ }^{1} \mathrm{H}-{ }^{13} \mathrm{C}$ heteronuclear single quantum coherence (HSQC) nuclear magnetic resonance (NMR) spectroscopy was employed to analyze lignin fraction. These ionic liquids were particularly effective to extract lignin from lignocelluloses to obtain cellulose-rich materials for biofuels.

Received 23rd July 2017

Accepted 22nd September 2017

DOI: $10.1039 / \mathrm{c} 7 \mathrm{ra0} 8110 \mathrm{c}$

rsc.li/rsc-advances allyl side chains coupled to various anions, such as chloride, acetate, and phosphonate, have been used in the pretreatment of lignocellulosic biomass. ${ }^{3-5}$

Ionic liquids are environmentally compatible solvents. They have high thermal stabilities and negligible vapor pressures; they do not release toxic or explosive gases when utilized. ${ }^{6}$ Previous studies on ILs have focused on lignin removal from lignocellulosic biomasses to improve the saccharification efficiency of lignocelluloses. Fu and Mazza reported 29\% total lignin removal from triticale straw using 1-ethyl-3methylimidazolium acetate $([\mathrm{Emim}] \mathrm{Cl})$ as a pretreated solvent at $150{ }^{\circ} \mathrm{C}$ for $1.5 \mathrm{~h}^{7}$ Wei et al. investigated 1-butyl-3methylimidazolium chloride $([\mathrm{Bmim}] \mathrm{Cl})$ as an IL solvent for the pretreatment of legume straw at $150{ }^{\circ} \mathrm{C}$ for $2 \mathrm{~h}$; the authors observed $30 \%$ lignin removal. ${ }^{8}$ Currently, more studies have been conducted regarding the lignin yield as lignin is a potential renewable source for valuable products. The pretreatment of corn stalks with [Emim]Ac at $125{ }^{\circ} \mathrm{C}$ for $1 \mathrm{~h}$ resulted in a $44 \%$ lignin yield. ${ }^{9}$ The fractionation of bagasse was performed at $110{ }^{\circ} \mathrm{C}$ for $16 \mathrm{~h}$ with choline acetate, and $20 \%$ of the lignin was fractionated as lignin-rich material. ${ }^{10}$

Ionic liquids, such as $[\mathrm{Emim}] \mathrm{Cl},[\mathrm{Bmim}] \mathrm{Cl}$ and $[\mathrm{Emim}] \mathrm{Ac}$ have been widely reported for the pretreatment of lignocelluloses, however, high pretreatment temperatures and long processing times are always required ${ }^{11} \mathrm{~A}$ ball mill was also used for $72 \mathrm{~h}$ before IL pretreatment. ${ }^{12}$ However, lignin regeneration is not very efficient using ILs such as [Bmim] Cl and [Emim]Ac. ${ }^{\mathbf{1 3 , 1 4}}$ In this study, a series of ionic liquids were synthesized and
${ }^{a}$ College of Life Science, Northeast Agricultural University, Harbin, 150030, China. E-mail: huxiaomei1982@163.com

${ }^{b}$ Heilongjiang Academy of Agricultural Sciences, Harbin, 150086, China ${ }^{c}$ Harbin University, Harbin, 150086, China. E-mail: bzhu@neau.edu.cn 
investigated for their activity on the pretreatment of poplar and bamboo flours.

\section{Experimental}

\subsection{Materials}

All chemicals were purchased from Aladdin Company (ShangHai, China) and used as received. Poplar flour and bamboo flour were purchased from Xingtang Xinlei Mineral Powder Factory (ShijiaZhuang, China). The poplar flour and bamboo flour were ground to an average particle size of less than 40 -mesh $(400 \mu)$ and stored in an air-tight container at room temperature until used.

\subsection{Composition of poplar and bamboo}

The samples $(300 \mathrm{mg}$ ) were hydrolyzed with $3 \mathrm{~mL}$ of $72 \%$ sulfuric acid and incubated for $1 \mathrm{~h}$ at $30{ }^{\circ} \mathrm{C}$ with stirring every $10 \mathrm{~min}$. The solution was then diluted to $4 \%$ sulfuric acid by adding $84 \mathrm{~mL}$ of deionized water. The mixture was autoclaved for $1 \mathrm{~h}$ at $121^{\circ} \mathrm{C}$. After the autoclave treatment, the solution was cooled and the suspended solids were removed by filtration. The filtrate was used to determine the carbohydrate content using high-performance liquid chromatography (HPLC, Agilent 1100, America). The cellulose and xylan contents were calculated from glucose and xylose contents multiplied by conversion factors of 0.90 and 0.88 , respectively. ${ }^{15}$ The filtrate of the acidsoluble lignin content from poplar was estimated by measuring the absorbance at $240 \mathrm{~nm}$ using UV-mini-1240 spectrometer (SHIMADZU). The filtered solids were dried at $105{ }^{\circ} \mathrm{C}$ until constant weight. Then the sample was burnt at $575{ }^{\circ} \mathrm{C}$ to determine the inorganic ash content. This ash is subtracted from $105{ }^{\circ} \mathrm{C}$ dried solids weight to obtain the acid insoluble lignin. ${ }^{15}$

\section{Methods}

\subsection{Synthesis of ionic liquids}

Pyridine $(0.3 \mathrm{~mol})$ and hydrochloric acid $(0.3 \mathrm{~mol})$ were added into a $100 \mathrm{~mL}$ round bottom flask and stirred under mechanical agitation at room temperature for $24 \mathrm{~h}$. The resulting mixture was washed with diethyl ether $(20 \mathrm{~mL} \times 3)$. Solvent residue was then evaporated using a rotary evaporator at $50{ }^{\circ} \mathrm{C}$ for $30 \mathrm{~min}$. The resulting product was further vacuum-dried at $60{ }^{\circ} \mathrm{C}$ for $24 \mathrm{~h}$ to give [Hpy]Cl. The synthesis of $1-H$-3-methy-limidazolium chloride $([\mathrm{Hmim}] \mathrm{Cl})$ and $N$-methyl-2-pyrrolidonium chloride ([Hnmp]Cl) followed protocols similar to those used for [Hpy] $\mathrm{Cl}^{16}$

\subsection{Pretreatment of lignocellulose}

Poplar or bamboo flour $(0.4 \mathrm{~g})$ was added to $8 \mathrm{~g}$ of the ionic liquid. The mixture was stirred at $90{ }^{\circ} \mathrm{C}$ or $100{ }^{\circ} \mathrm{C}$ for $30 \mathrm{~min}$. An acetone/deionized water $(1 / 1, \mathrm{v} / \mathrm{v})$ solution $(30 \mathrm{~mL})$ was then added into the ionic liquid mixture. The resulting solid was filtered, washed with $30 \mathrm{~mL}$ of acetone/deionized water $(1 / 1, \mathrm{v} /$ v), and dried under a vacuum at $60^{\circ} \mathrm{C}$ for $24 \mathrm{~h}$ to yield celluloserich materials. Acetone was then removed from the filtrate by rotary evaporation. The resulting product was filtered, further washed with $20 \mathrm{~mL}$ of deionized water, and vacuum-dried at $60{ }^{\circ} \mathrm{C}$ for $24 \mathrm{~h}$ to yield regenerated lignin. The yields of the cellulose-rich materials and extracted lignin were calculated according to eqn (1) and (2), respectively. The ionic liquid was recycled and concentrated for reuse.

$$
\begin{aligned}
& \text { Cellulose-rich materials yield }(\%)= \\
& \frac{\text { cellulose-rich materials }(\mathrm{mg})}{\text { biomass }(\mathrm{mg})} \times 100 \% \\
& \text { Lignin content yield }(\%)=\frac{\text { recover lignin }(\mathrm{mg})}{\text { original content of lignin }(\mathrm{mg})} \\
& \times 100 \%
\end{aligned}
$$

\subsection{Fourier transform infrared (FTIR) analysis}

FTIR analysis was performed on a FTIR spectrophotometer (Bruker ALPHA-T, Karlsruhe, Germany). The operating system used was Spectrum software (OPUS 6.5, Bruker Optics, Karlsruhe, Germany). Approximately $0.5 \mathrm{mg}$ of the sample was mixed with $\mathrm{KBr}$. The sample was then placed in a press and pressed with 16 tons of pressure for $2 \mathrm{~min}$. The FTIR spectra were recorded for the pellets over the $4000 \mathrm{~cm}^{-1}$ to $400 \mathrm{~cm}^{-1}$ region, with a total of 16 scans and a resolution of $4 \mathrm{~cm}^{-1}$. The FTIR spectra were recorded using a blank $\mathrm{KBr}$ pellet as the background.

\subsection{Scanning electron microscopy (SEM)}

SEM images were taken for both untreated and pretreated poplar and bamboo solids using a Hitachi S-3400N microscope. Prior to acquiring images, the samples were mounted with double sided carbon tape on precut brass sample stubs and sputter coated with approximately 30 angstrom of $\mathrm{Au} / \mathrm{Pd}$. The representative images of ionic liquid-pretreated poplar and bamboo were acquired with a $5 \mathrm{kV}$ accelerating voltage.

\subsection{X-ray diffractometry}

$\mathrm{X}$-ray diffractometry was conducted on D/max-2500PC diffractometer (Japan) equipped with $\mathrm{Cu} \mathrm{K} \alpha$ radiation over the range of $5-60^{\circ}$ with a step of $4^{\circ}$ at $40 \mathrm{kV}$ and $100 \mathrm{~mA}$. The crystallinity, as expressed by the crystallinity index (CrI), was determined by Segal method. ${ }^{17}$ The following empirical equation was adopted to estimate the crystallinity index:

$$
\mathrm{CrI}(\%)=100 \times \frac{I_{\text {total }}-I_{\mathrm{am}}}{I_{\text {total }}}
$$

In which $I_{\text {total }}$ is the scattered intensity at the main peaks, whereas $I_{\mathrm{am}}$ is the scattered intensity due to the amorphous portion. ${ }^{18}$

\subsection{Enzymatic hydrolysis}

Enzymatic hydrolysis was performed with a biomass loading of $1 \%\left(\mathrm{~g} \mathrm{~mL}^{-1}\right)$ and $0.02 \mathrm{~g}$ of cellulase in $0.1 \mathrm{M}$ sodium citrate buffer ( $\mathrm{pH} 4.8)$ on a shaker at $150 \mathrm{rpm}, 50{ }^{\circ} \mathrm{C}$ for $72 \mathrm{~h}$. After that time, the mixture was heated at $100{ }^{\circ} \mathrm{C}$ for $10 \mathrm{~min}$. The reducing 
sugars were measured by the DNS method. ${ }^{19}$ The yields of glucose, xylose and cellobiose were measured by HPLC and calculated according to eqn (4).

Sugar $(\%)=$

$$
\begin{aligned}
& \text { glucose, cellobiose, xylose }(\mathrm{mg}) \\
& \text { cellulose-rich materials subjected to enzymatic hydrolysis }(\mathrm{mg}) \\
& \times 100 \%
\end{aligned}
$$

\subsection{Nuclear magnetic resonance (NMR) analysis}

${ }^{1} \mathrm{H}-{ }^{13} \mathrm{C}$ correlation 2D NMR heteronuclear single quantum correlation spectra were recorded on a Bruker AV-III $400 \mathrm{MHz}$ spectrometer (ShangHai, China) at $25{ }^{\circ} \mathrm{C}$. A mixture of DMSO$\mathrm{d}_{6} /$ pyrimidine $(4: 1, \mathrm{v} / \mathrm{v})$ was used as the solvent for sample handing. ${ }^{20}$

\section{Results and discussion}

The composition of the poplar and bamboo was analyzed using the National Renewable Energy Laboratory standard procedure. ${ }^{15}$ Poplar consisted of $42.5 \%$ cellulose, $10.0 \%$ hemicelluloses, and $23.5 \%$ lignin. Bamboo contained $36.3 \%$ cellulose, $12.6 \%$ hemicelluloses, and $30.6 \%$ lignin.

\subsection{Determination of lignin}

Higher pretreatment temperatures accelerated the swelling and dissolution rates of lignocelluloses in ILs. ${ }^{\mathbf{2 1 , 2 2}}$ Higher temperatures could effectively disrupt the recalcitrant structure of lignocelluloses to release lignin. Vo et al. $^{23}$ demonstrated that milled poplar could be dissolved in 1-ethyl-3-methylimidazolium acetate ([Bmim]Ac) at $130{ }^{\circ} \mathrm{C}$ for $12 \mathrm{~h}$; the procedure yielded $31.9 \%$ of the original lignin. With lower pretreatment temperatures, longer times were required for efficient lignin extractions of biomasses. $\mathrm{Xu}$ et $a .^{24}$ reported that rice straw pretreated with 1-ethyl-3methylimidazolium phosphinate $\left([\mathrm{Emim}]\left[\mathrm{H}_{2} \mathrm{PO}_{2}\right]\right),[$ Emim $] \mathrm{Ac}$, and $[\mathrm{Emim}] \mathrm{Cl}$ at $110{ }^{\circ} \mathrm{C}$ for $24 \mathrm{~h}$ resulted in lignin extraction rates of $55.6 \%, 47.8 \%$, and $14.6 \%$, respectively, when determined from the UV-vis absorbance at $280 \mathrm{~nm}$. Compared with current studies
(Table 1), a low pretreatment temperature and a short time were used in this work.

In this study, the yield of the lignin extracted was calculated according to eqn (2). As the temperature increased from $90{ }^{\circ} \mathrm{C}$ to $100{ }^{\circ} \mathrm{C}$ (Fig. 1), lignin regeneration improved from $51.3 \%$ to $61.0 \%$ with [Hpy]Cl-treatment. Lignin yield improved from $49.3 \%$ to $60.4 \%$ with [Hmim]Cl-treatment, and the yield improved from $38.7 \%$ to $47.9 \%$ with [Hnmp]Cl-treatment. Thus, high lignin yields of $61.0 \%$ and $60.4 \%$ were achieved when the poplar was pretreated at $100{ }^{\circ} \mathrm{C}$ for $30 \mathrm{~min}$ with [Hpy] $\mathrm{Cl}$ and $[\mathrm{Hmim}] \mathrm{Cl}$, respectively.

In addition, as the temperature increased from $90{ }^{\circ} \mathrm{C}$ to $100{ }^{\circ} \mathrm{C}$, lignin regeneration improved from $42.6 \%$ to $51.7 \%$ with [Hpy]Cl-treatment. Lignin yield improved from $26.6 \%$ to $50.3 \%$ with [Hnmp]Cl-treatment, and the yield improved from 39.9\% to $43.7 \%$ with [Hmim]Cl-treatment. Thus, high lignin yields of $51.7 \%$ and $50.3 \%$ were obtained from bamboo treated with [Hpy]Cl and [Hnmp]Cl, respectively (Fig. 2).

The degree of biomass recalcitrance varies among the biomass species. Fort et $a .^{25}$ proposed that wood type and species affected the dissolution ability. In this study, lignin yields of $38.7 \%$ to $61.0 \%$ were obtained from poplar, and lignin yields of $26.6 \%$ to $51.7 \%$ were extracted from bamboo. A lower lignin yield was recovered from bamboo due to its recalcitrant structure. Although ball milling of bamboo for $72 \mathrm{~h}$ before ILpretreatment was required, ${ }^{\mathbf{1 2}}$ the milling process was not employed when using these ILs in this work.

When compared to contemporary studies, a low pretreatment temperature and a short processing time were employed using these ionic liquids, they resulted in obtaining high lignin yield (Table 1). For example, $31.90 \%$ of the lignin was extracted from poplar in [Emim]Ac at $130{ }^{\circ} \mathrm{C}$ for $12 \mathrm{~h} .{ }^{26}$ Poplar pretreated with [Emim]Ac for $1 \mathrm{~h}$ at $125{ }^{\circ} \mathrm{C}$ resulted in $10.1 \%$ lignin removal. ${ }^{27} \mathrm{In}$ this work, more than $60 \%$ lignin removal was achieved from poplar with $[\mathrm{Hpy}] \mathrm{Cl}$ and $[\mathrm{Hmim}] \mathrm{Cl}$ at $100{ }^{\circ} \mathrm{C}$ for $30 \mathrm{~min}$.

\subsection{Determination of cellulose-rich materials}

The yields of cellulose-rich materials were calculated according to eqn (1). As shown in Fig. 3 and 4, when the temperature

\begin{tabular}{|c|c|c|c|c|c|c|}
\hline Ionic liquid & Biomass & Temp. $\left({ }^{\circ} \mathrm{C}\right)$ & Time (h) & $\begin{array}{l}\text { Biomass mass/ILs } \\
\text { mass }(\%)\end{array}$ & $\begin{array}{l}\text { Lignin extraction } \\
\text { yield (\%) }\end{array}$ & Ref. \\
\hline$[\mathrm{Emim}] \mathrm{Cl}$ & Triticale straw & 150 & 1.5 & $5(w / w)$ & 29 & 28 \\
\hline$\left[\mathrm{C}_{4} \mathrm{C}_{1} \mathrm{im}\right] \mathrm{Cl}$ & Legume straw & 150 & 2 & $5(w / w)$ & 30 & 8 \\
\hline$[\mathrm{Emim}] \mathrm{Ac}$ & Triticale straw & 130 & 1.5 & $5(w / w)$ & 41 & 7 \\
\hline [Emim]Ac & Poplar & 130 & 12 & $5(w / w)$ & 31.90 & 26 \\
\hline [Emim]Ac & Poplar & 125 & 1 & $33.3(\mathrm{w} / \mathrm{w})$ & 10.1 & 27 \\
\hline$[\mathrm{Bmim}] \mathrm{Ac} / \mathrm{H}_{2} \mathrm{O}$ & Willow & 120 & 22 & $10(\mathrm{w} / \mathrm{v})$ & 46.7 & 29 \\
\hline$[$ Emim $]$ Ac & Southern yellow pine & 110 & 16 & $5(\mathrm{w} / \mathrm{w})$ & 31.4 & 30 \\
\hline$[\mathrm{Emim}] \mathrm{Ac}$ & Maple wood flour & 90 & 24 & $5(w / w)$ & 37 & 31 \\
\hline$[\mathrm{Hpy}] \mathrm{Cl}$ & Poplar & 100 & 0.5 & $5(w / w)$ & 61.0 & \\
\hline$[\mathrm{Hmim}] \mathrm{Cl}$ & Poplar & 100 & 0.5 & $5(w / w)$ & 60.4 & \\
\hline$[\mathrm{Hpy}] \mathrm{Cl}$ & Bamboo & 100 & 0.5 & $5(w / w)$ & 51.7 & \\
\hline$[\mathrm{Hnmp}] \mathrm{Cl}$ & Bamboo & 100 & 0.5 & $5(w / w)$ & 50.3 & \\
\hline
\end{tabular}
increased from $90{ }^{\circ} \mathrm{C}$ to $100{ }^{\circ} \mathrm{C}$, the yield of cellulose-rich

Table 1 Comparison of lignin extraction in various ILs 


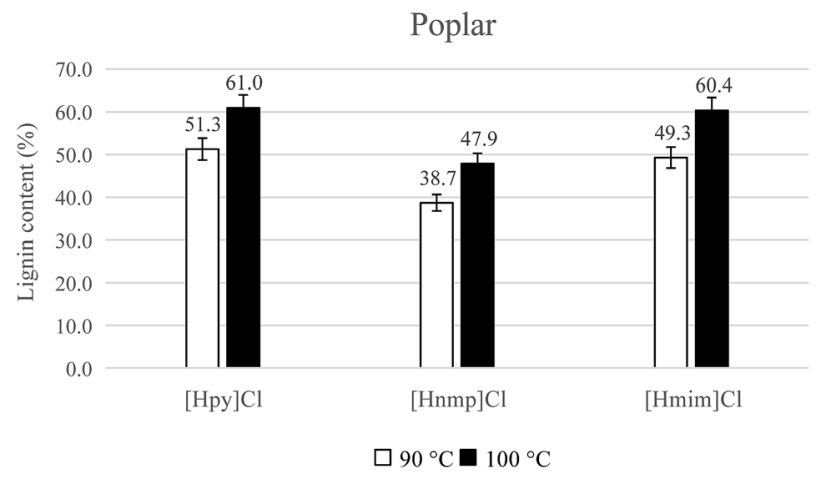

Fig. 1 The extracted lignin content from poplar.

materials decreased from $59.7 \%$ to $37.1 \%$ for poplar with [Hpy] Cl-treatment (Fig. 3). When the temperature increased from $90{ }^{\circ} \mathrm{C}$ to $100{ }^{\circ} \mathrm{C}$, the yield of cellulose-rich materials decreased from $76.1 \%$ to $53.0 \%$ for bamboo with [Hnmp]Cl-pretreatment (Fig. 4). Increased temperatures resulted in the efficient lignin extraction and the reduced yields of cellulose-rich materials.

\subsection{FTIR analysis of cellulose-rich materials from lignocelluloses}

The FTIR spectra of cellulose-rich materials from poplar are illustrated in Fig. 5. The absorbances at 3427, 2923, 1433, 1378, $1334,1163,1108,1057$, and $889 \mathrm{~cm}^{-1}$ are associated with cellulose. Typically, the absorption at $3427 \mathrm{~cm}^{-1}$ is associated with the $\mathrm{O}-\mathrm{H}$ stretching. The peak at $2923 \mathrm{~cm}^{-1}$ is attributed to C-H stretching. A peak at $1433 \mathrm{~cm}^{-1}$ is related to $\mathrm{CH}_{2}$ symmetric bending. The absorbance at $1378 \mathrm{~cm}^{-1}$ is related to $\mathrm{CH}$ bending. The peak at $1334 \mathrm{~cm}^{-1}$ is related to the $\mathrm{CH}_{2}$ bending of the carbohydrates, whereas the $1163 \mathrm{~cm}^{-1}$ peak is attributed to $\mathrm{C}-\mathrm{O}$ antisymmetric stretching. The absorbance at $1111 \mathrm{~cm}^{-1}$ is related to $\mathrm{C}-\mathrm{OH}$ skeletal vibration, and the absorbance at $1053 \mathrm{~cm}^{-1}$ is due to the $\mathrm{C}-\mathrm{O}-\mathrm{C}$ pyranose ring skeletal vibration. The peak at $889 \mathrm{~cm}^{-1}$ corresponds to the glycosidic $\mathrm{C}_{1}-\mathrm{H}$ deformation with ring vibration contribution, which is a characteristic of the $\beta$-glycosidic linkages between glucose monomers in cellulose.

The FTIR spectra of cellulose-rich materials from bamboo are illustrated in Fig. 6. The absorbance at 3442, 2912, 1458,

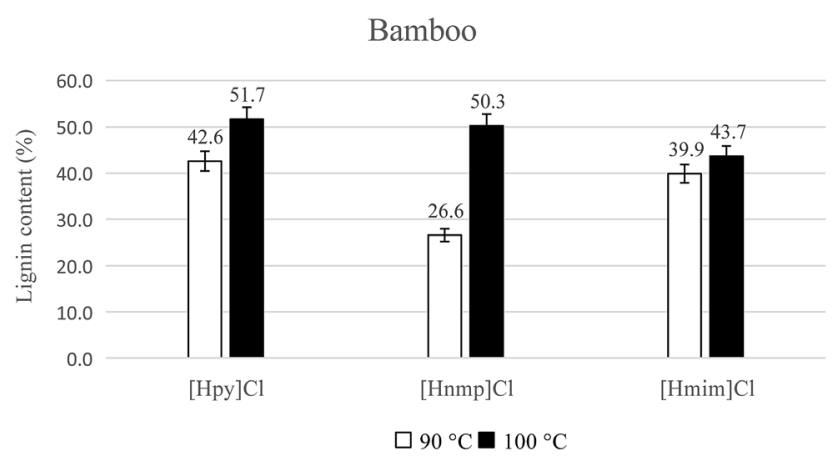

Fig. 2 The extracted lignin content from bamboo.

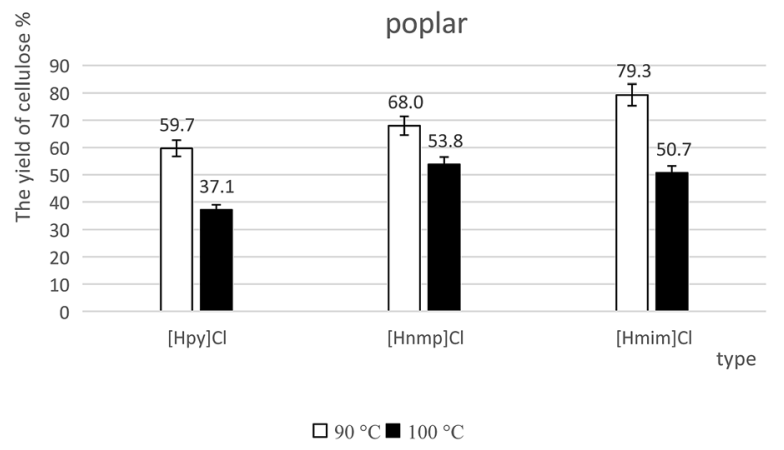

Fig. 3 The yields of cellulose-rich materials from poplar.

1371, 1327, 1166, 1049, and $900 \mathrm{~cm}^{-1}$ are associated with cellulose. Typically, the absorption at $3427 \mathrm{~cm}^{-1}$ is associated with the $\mathrm{O}-\mathrm{H}$ stretching. The $2912 \mathrm{~cm}^{-1}$ peak is attributed to $\mathrm{C}-\mathrm{H}$ stretching. A peak at $1422 \mathrm{~cm}^{-1}$ is related to $\mathrm{CH}_{2}$ symmetric bending, whereas the $1371 \mathrm{~cm}^{-1}$ peak is related to $\mathrm{CH}$ bending. The absorbance at $1327 \mathrm{~cm}^{-1}$ is related to $\mathrm{CH}_{2}$ bending of carbohydrates. The $1166 \mathrm{~cm}^{-1}$ peak is attributed to $\mathrm{C}-\mathrm{O}$ antisymmetric stretching. The $1111 \mathrm{~cm}^{-1}$ absorbance is related to $\mathrm{C}-\mathrm{OH}$ skeletal vibration, whereas the $1049 \mathrm{~cm}^{-1}$ absorbance is attributed to the $\mathrm{C}-\mathrm{O}-\mathrm{C}$ pyranose ring skeletal vibration. The peak at $900 \mathrm{~cm}^{-1}$ is related to the glycosidic $\mathrm{C}_{1}-\mathrm{H}$ deformation with ring vibration contribution.

\subsection{FTIR analysis of lignin from poplar}

The peaks at $3423,2938,1710,1601,1510,1462,1426,1331$, $1272,1225,1126,1035$, and $830 \mathrm{~cm}^{-1}$ are associated with ILextracted lignin from poplar (Fig. 7). Typically, the peaks at $1601 \mathrm{~cm}^{-1}$ and $1510 \mathrm{~cm}^{-1}$ are attributed to the aromatic skeletal vibrations. The peak at $1462 \mathrm{~cm}^{-1}$ is related to $\mathrm{C}-\mathrm{H}$ deformations. The peak at $1426 \mathrm{~cm}^{-1}$ is associated with aromatic skeletal vibrations combined with $\mathrm{C}-\mathrm{H}$ in-plane deformation. The peak at $1331 \mathrm{~cm}^{-1}$ is related to syringyl unit (S) vibration breathing with $\mathrm{C}=\mathrm{O}$ stretching and to condensed guaiacyl unit (G) rings. The peak at $1272 \mathrm{~cm}^{-1}$ is related to $\mathrm{G}$ ring breathing with carbonyl stretching. The peak at $1225 \mathrm{~cm}^{-1}$ is associated with $\mathrm{C}-\mathrm{C}, \mathrm{C}-\mathrm{O}$, and $\mathrm{C}=\mathrm{O}$ stretching. The peak at $1126 \mathrm{~cm}^{-1}$ is attributed to ether. The peak at $1035 \mathrm{~cm}^{-1}$ is associated with aromatic $\mathrm{C}-\mathrm{H}$ in-plane deformation and with $\mathrm{C}-\mathrm{O}$ deformation

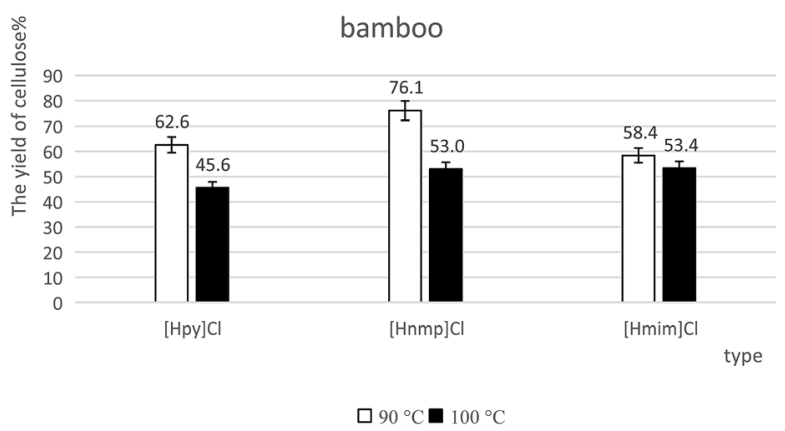

Fig. 4 The yields of cellulose-rich materials from bamboo. 


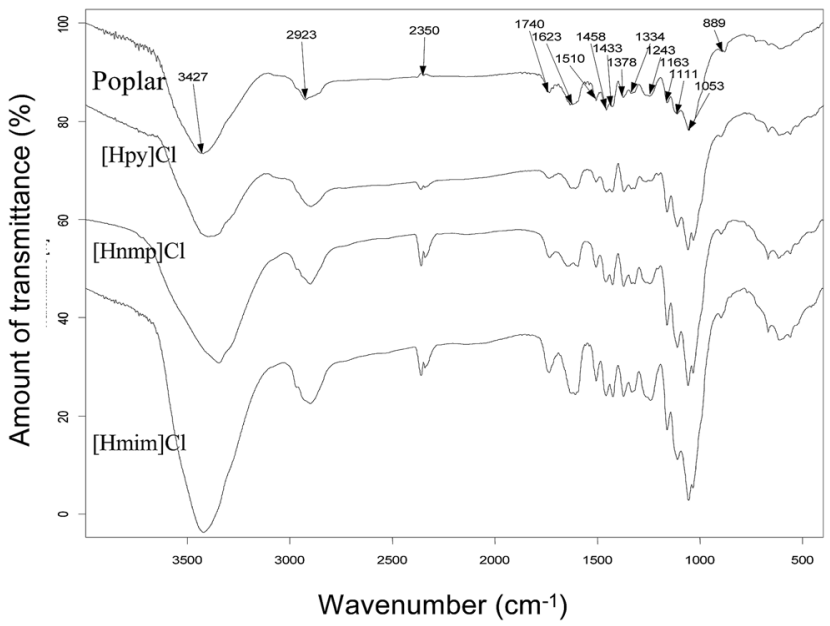

Fig. 5 FTIR spectra of cellulose-rich materials from poplar at $90{ }^{\circ} \mathrm{C}$.

in primary alcohols, as well as $\mathrm{C}=\mathrm{O}$ stretching. The peak at $830 \mathrm{~cm}^{-1}$ is C-H out-of-plane deformation of S rings. ${ }^{32}$

\subsection{FTIR analysis of lignin from bamboo}

The peaks at 3431, 2938, 1703, 1605, 1513, 1462, 1426, 1331, $1225,1166,1126,1035$, and $834 \mathrm{~cm}^{-1}$ are attributed to alkali lignin (Fig. 8). Typically, the peaks at $1605 \mathrm{~cm}^{-1}, 1513 \mathrm{~cm}^{-1}$, and $1426 \mathrm{~cm}^{-1}$ are attributed to aromatic skeletal vibrations. Similarly, the peak at $1462 \mathrm{~cm}^{-1}$ is the result of $\mathrm{C}-\mathrm{H}$ deformations. The peak at $1331 \mathrm{~cm}^{-1}$ is related to syringyl unit (S) vibrations. The peak at $1225 \mathrm{~cm}^{-1}$ is from $\mathrm{C}-\mathrm{C}, \mathrm{C}-\mathrm{O}$, and $\mathrm{C}=\mathrm{O}$ stretching. ${ }^{33}$ The peak at $1125 \mathrm{~cm}^{-1}$ is attributed to ether-OThe peak at $1035 \mathrm{~cm}^{-1}$ is associated with aromatic $\mathrm{C}-\mathrm{H}$ in-plane deformation. The peak at $834 \mathrm{~cm}^{-1}$ is associated with $\mathrm{C}-\mathrm{H}$ outof-plane deformation of $\mathrm{S}$ rings.

Furthermore, the intensity of the peak at $1710 \mathrm{~cm}^{-1}$ was strong in the spectra with [Hpy]Cl and [Hmim] $\mathrm{Cl}$ pretreatments for bamboo, but weak in the spectra with [Hnmp]Cl pretreatment. This peak was associated with $\mathrm{C}=\mathrm{O}$ stretching that

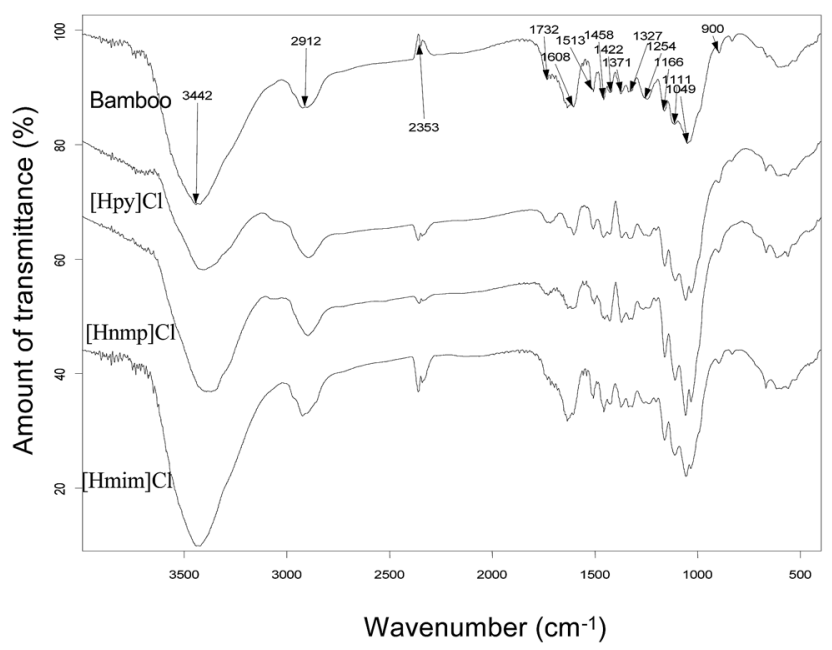

Fig. 6 FTIR spectra of cellulose-rich materials from bamboo at $90{ }^{\circ} \mathrm{C}$.

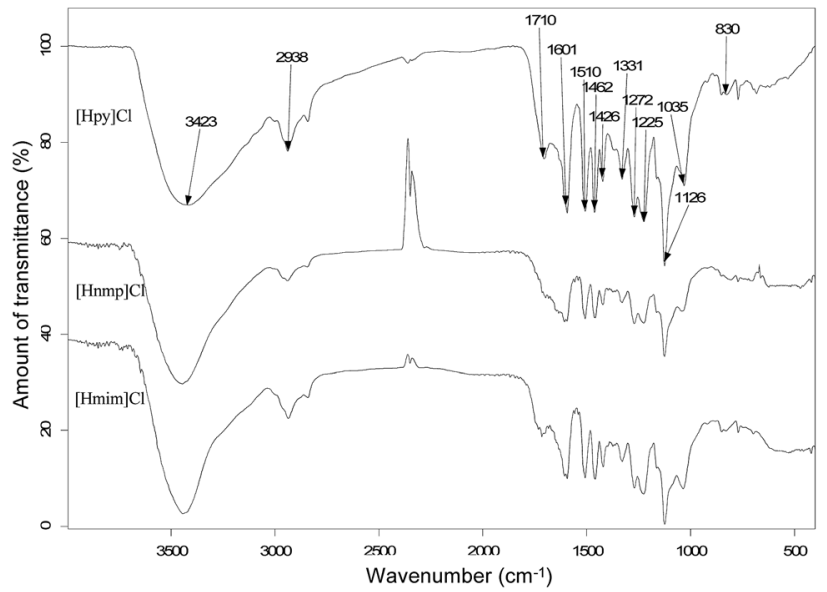

Fig. 7 FTIR spectra of IL-extracted lignin from poplar at $90^{\circ} \mathrm{C}$.

indicated hydroxycinnamates, for example, ferulate. Ferulate esterified with an arabinosyl unit in hemicelluloses was attached to lignin with an ether bond to form a carbohydratesferulate-lignin bridge structure. With [Hnmp]Cl pretreatment, lignin containing the bridge structure could not be dissolved in acetone/water, resulting in the decreased content of ferulate in lignin fraction. ${ }^{33}$

Comparisons of the FTIR spectra of poplar with that of bamboo showed some slight differences, for instance, the peak at $1272 \mathrm{~cm}^{-1}$ that was associated with $\mathrm{G}$ ring breathing with carbonyl stretching. This peak was prominent in poplar lignin indicating more $\mathrm{G}$ unit than bamboo lignin.

\subsection{Scanning electron microscopy analysis}

The structural changes in morphology of the lignocellusic biomass before and after IL-pretreatment were analyzed by SEM. As shown in Fig. 9, the original untreated lignocelluloses had the compact ordered and rigid fibril structures, however, the significant morphological modification for both of the bamboo and poplar was observed after ionic liquids pretreatment. Specifically, for poplar, the structure was loosened and

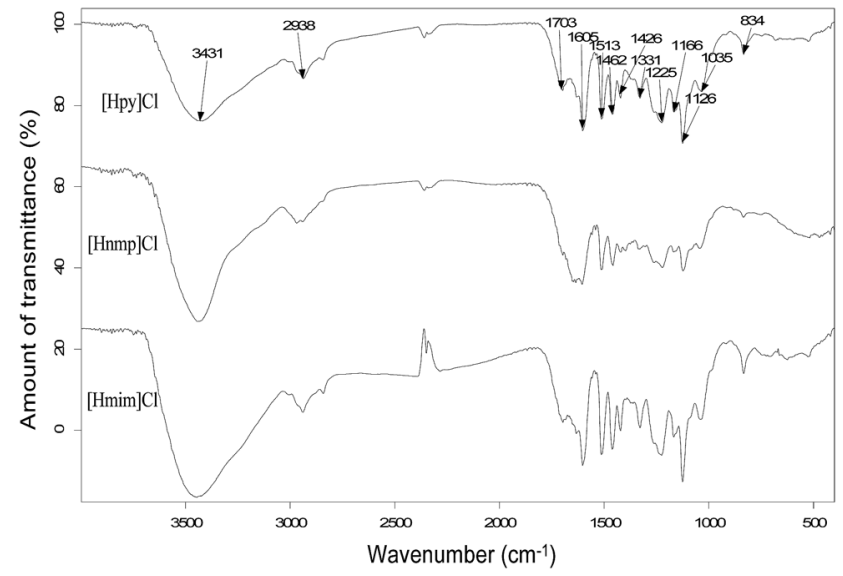

Fig. 8 FTIR spectra of IL-extracted lignin from bamboo at $90^{\circ} \mathrm{C}$. 

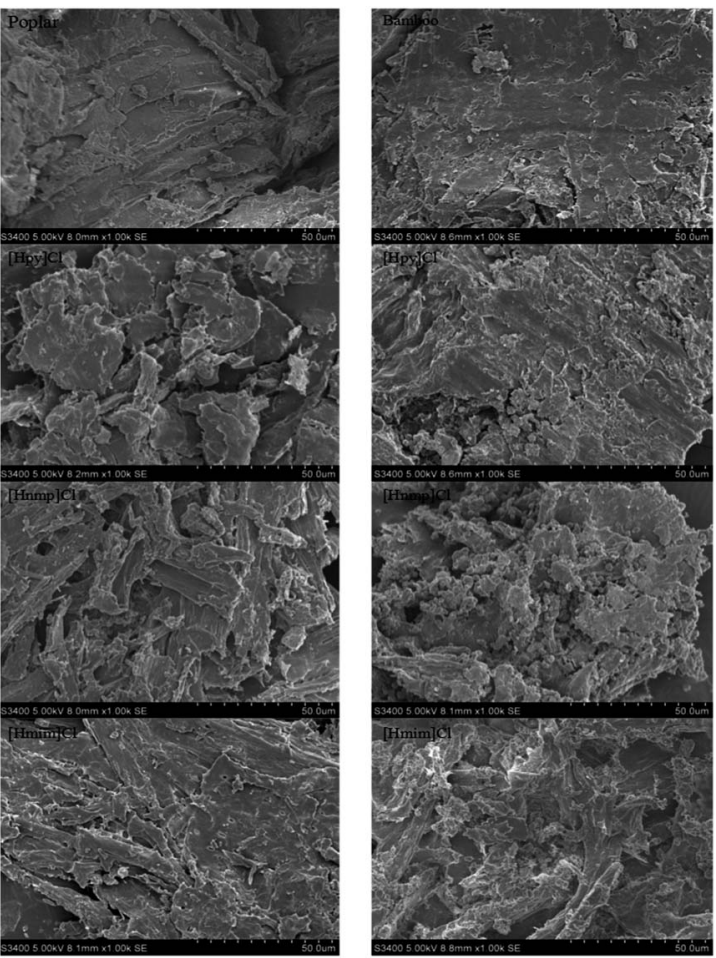

Fig. 9 SEM analysis of untreated and IL-pretreated poplar and bamboo

less compact after $[\mathrm{Hpy}] \mathrm{Cl}$ pretreatment. For bamboo, the surface of the residue become irregular after [Hmim]Cl treatment. The alteration of morphology indicated the disruption of linkages in lignocellulose during IL-pretreatment, providing a more accessible surface to cellulose, leading to enhanced enzymatic digestibility. ${ }^{8}$

\subsection{X-ray diffraction analysis}

The untreated and pretreated cellulose-rich materials of poplar and bamboo were determined by X-ray diffraction and the results were shown in Fig. 10 and 11.

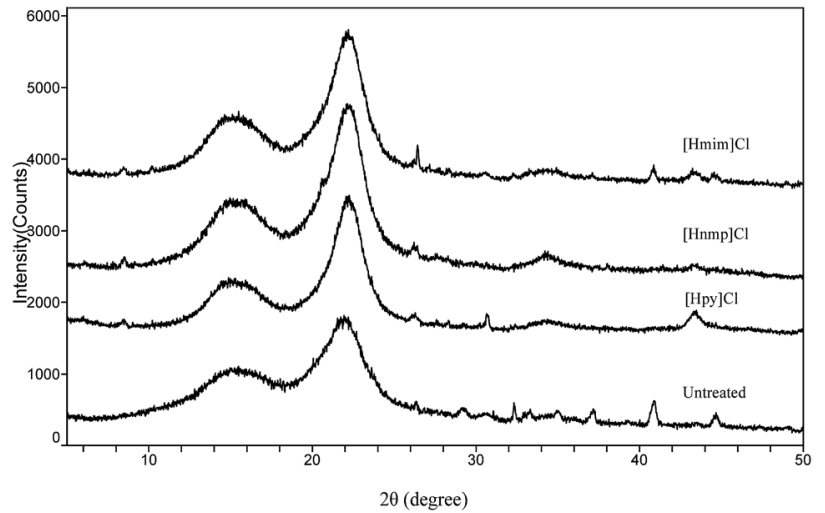

Fig. $10 \mathrm{XRD}$ analysis of untreated poplar and the cellulose-rich materials.

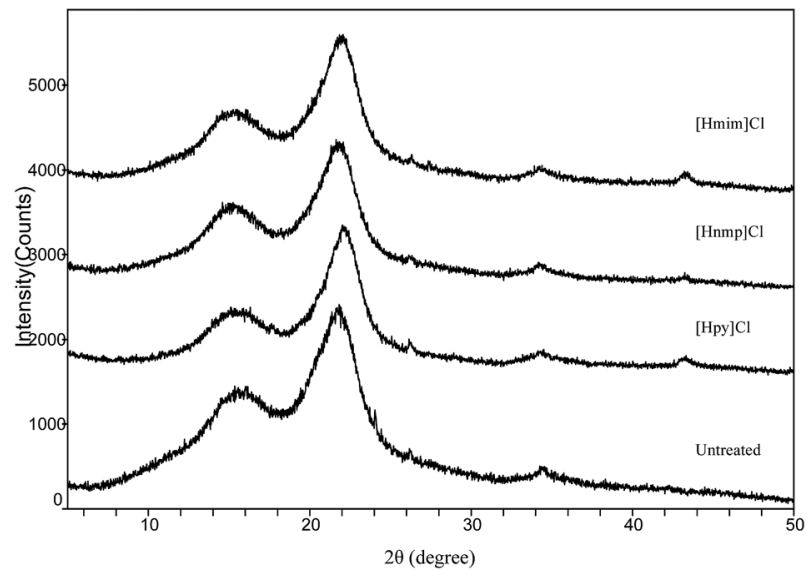

Fig. 11 XRD analysis of untreated bamboo and the cellulose-rich material.

For poplar and bamboo, all samples showed major intensive peaks related to their crystalline structures at $2 \theta$ values of around $15.5^{\circ}$ and $22.2^{\circ}$, indicating that the crystallinity of the samples were not significantly changed by IL pretreatment. ${ }^{34}$ The peak intensities of the IL treated samples were slightly increased compared to those of the untreated samples, which was consistent with the current reports. ${ }^{35}$ The cellulose-rich material crystal structure was unaffected by delignification, but the CrI of the biomass was increased owing to lignin removal. ${ }^{36}$ In addition, the peaks around $2 \theta=15.5^{\circ}$ and $22.2^{\circ}$ were sharper for the IL pretreated poplar and bamboo, which were typical peak for the cellulose $\mathrm{I}^{37}$

\subsection{Enzymatic hydrolysis}

The results of enzymatic hydrolysis of original biomass and ILtreated biomass are summarized in Tables 2 and 3. After $72 \mathrm{~h}$, high yields of glucose, cellobiose and xylose were $67.5 \%, 4.2 \%$ and $10.4 \%$, respectively, pretreated by [Hpy]Cl from poplar at

Table 2 Enzymatic hydrolysis of cellulose from poplar

\begin{tabular}{|c|c|c|c|c|c|c|}
\hline \multirow[b]{2}{*}{ Biomass pretreated } & \multicolumn{2}{|c|}{ Glucose (\%) } & \multicolumn{2}{|c|}{ Cellobiose (\%) } & \multicolumn{2}{|c|}{ Xylose $(\%)$} \\
\hline & Ave (\%) & Std. & Ave $(\%)$ & Std. & Ave $(\%)$ & Std. \\
\hline Poplar & 46.4 & 0.37 & 5.5 & 0.89 & 7.3 & 1.24 \\
\hline$[\mathrm{Hpy}] \mathrm{Cl}$ & 67.5 & 1.42 & 4.2 & 1.07 & 10.4 & 0.60 \\
\hline$[\mathrm{Hnmp}] \mathrm{Cl}$ & 62.3 & 0.86 & 3.6 & 1.23 & 8.1 & 0.77 \\
\hline$[\mathrm{Hmim}] \mathrm{Cl}$ & 62.0 & 0.94 & 3.1 & 0.42 & 8.0 & 1.19 \\
\hline
\end{tabular}

Table 3 Enzymatic hydrolysis of cellulose from bamboo

\begin{tabular}{|c|c|c|c|c|c|c|}
\hline \multirow[b]{2}{*}{ Biomass pretreated } & \multicolumn{2}{|c|}{ Glucose (\%) } & \multicolumn{2}{|c|}{ Cellobiose (\%) } & \multicolumn{2}{|c|}{ Xylose $(\%)$} \\
\hline & Ave (\%) & Std. & Ave $(\%)$ & Std. & Ave (\%) & Std. \\
\hline Bamboo & 42.0 & 0.55 & 4.5 & 0.41 & 8.4 & 0.34 \\
\hline$[\mathrm{Hpy}] \mathrm{Cl}$ & 63.5 & 0.94 & 2.2 & 0.73 & 8.0 & 0.68 \\
\hline$[\mathrm{Hnmp}] \mathrm{Cl}$ & 60.8 & 0.53 & 2.5 & 1.12 & 8.4 & 0.90 \\
\hline$[\mathrm{Hmim}] \mathrm{Cl}$ & 65.5 & 1.03 & 7.1 & 0.41 & 11.8 & 1.09 \\
\hline
\end{tabular}



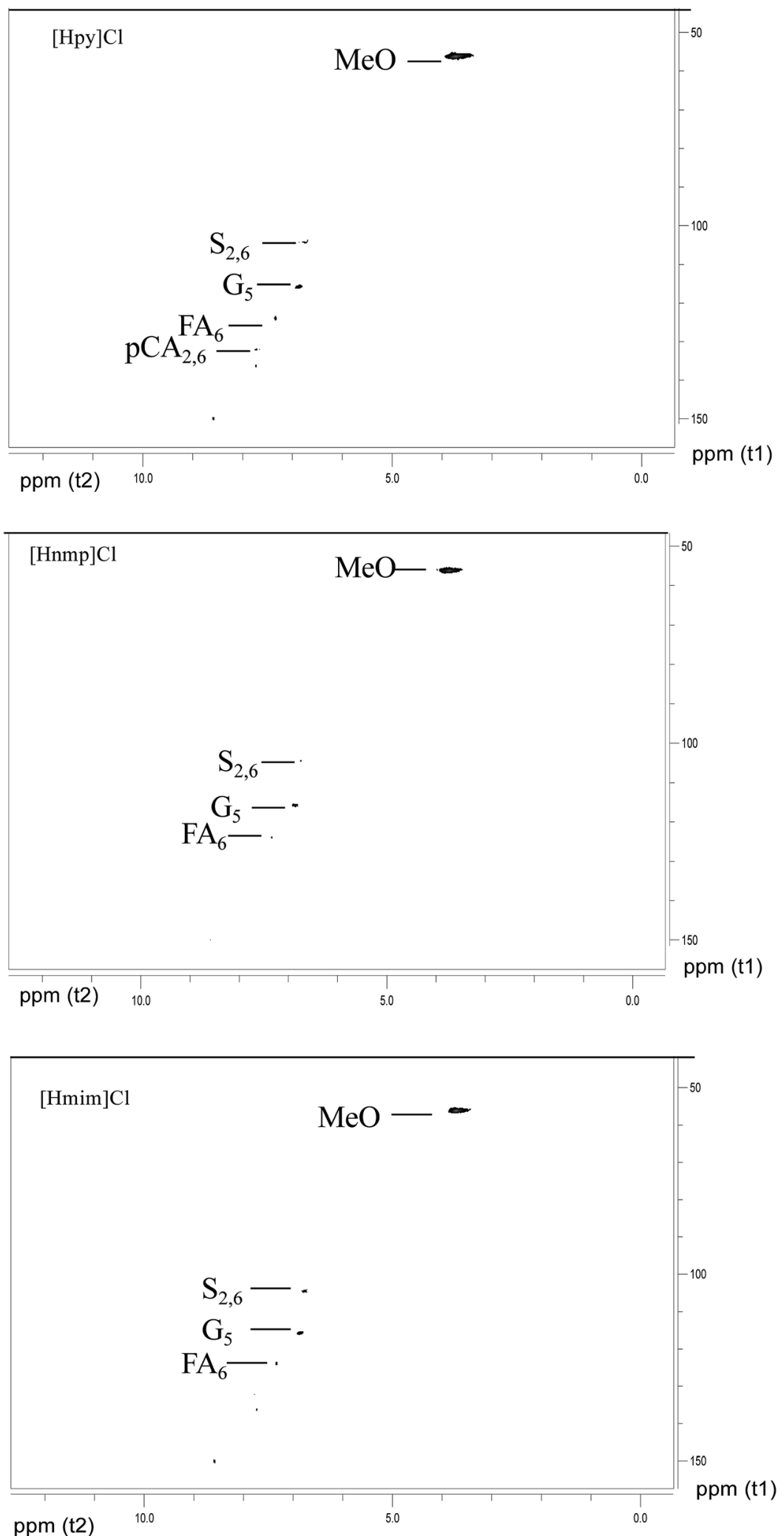

Fig. 12 2D-NMR (HSQC) spectra of IL-extracted lignin from poplar.

$90{ }^{\circ} \mathrm{C}$ for $30 \mathrm{~min}$. Good yields of glucose, cellobiose and xylose were $65.5 \%, 7.1 \%$ and $11.8 \%$ in [Hmim]Cl-treated bamboo sample at $90{ }^{\circ} \mathrm{C}$ for $30 \mathrm{~min}$, respectively.
The capability of ionic liquids could destruct the link of lignocelluloses and then to remove the lignin content effectively. The significantly reduction lignin resulted in the high 

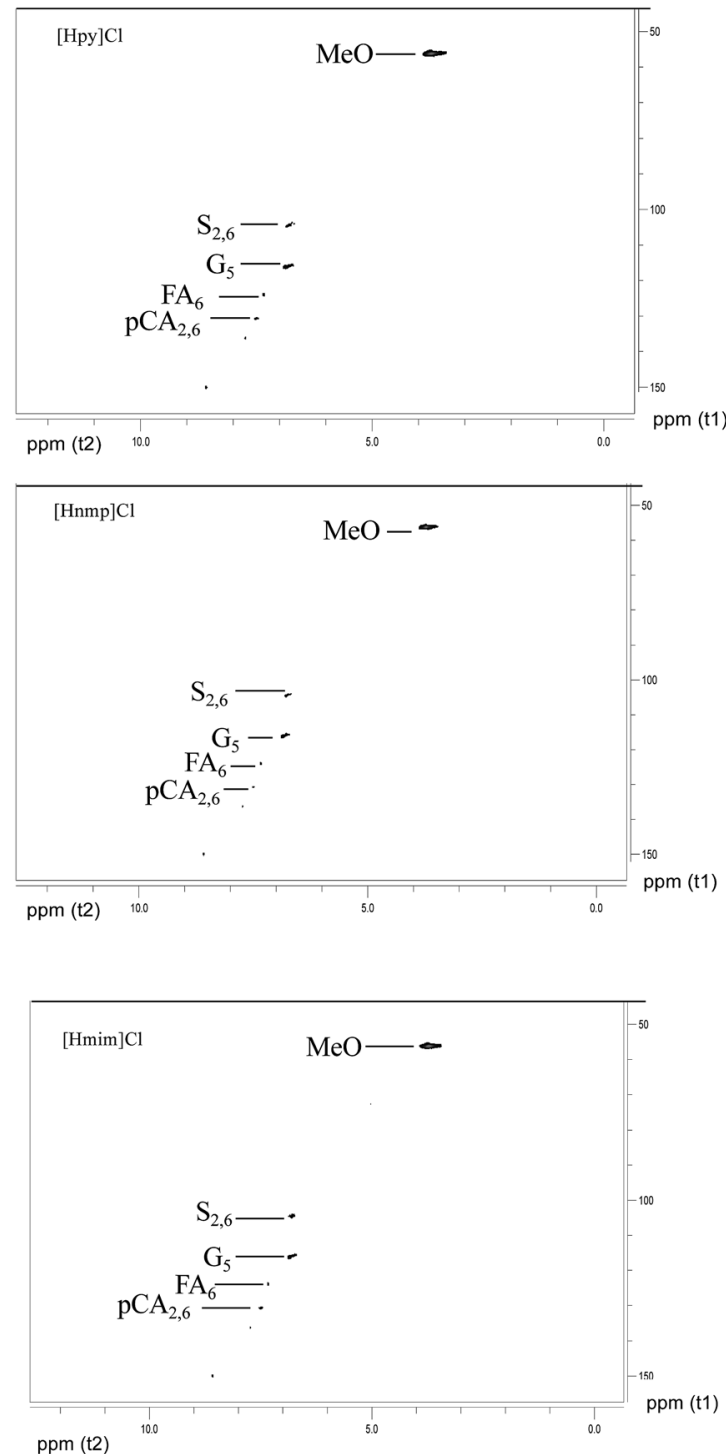

Fig. 13 2D-NMR (HSQC) spectra of IL-extracted lignin from bamboo.

enzyme digestibility of cellulose. The reduced lignin in cellulose-rich materials were also confirmed by FTIR analysis. Moreover, SEM image showed the significant structural changes in morphology, which released a large area on the fiber surface, consequently improving the accessibility of cellulose and the enzymatic efficiency. Ionic liquids pretreatment in this work contributed to achieve the high yield of IL-isolated lignin and the high enzymatic digestibility of cellulose.

\subsection{HSQC NMR analysis}

The IL-extracted lignin was analyzed by $2 \mathrm{D}{ }^{1} \mathrm{H}-{ }^{13} \mathrm{C}$ HSQC (Heteronuclear Single Quantum Correlation) NMR. As shown in Fig. 12, the signals at 56.139/3.731 ppm, 115.670/6.860 ppm, 123.920/7.342 ppm, 136.214/7.746 ppm, and 149.965/8.594 ppm are associated with poplar lignin. In general, the signal at $56.139 / 3.731 \mathrm{ppm}$ is from methoxyl groups (MeO) in the aliphatic region. The aromatic region of lignin is from $100 \mathrm{ppm}$ to $155 \mathrm{ppm}$. Typically, a signal at $115.670 / 6.860 \mathrm{ppm}$ is from $\mathrm{C}_{5^{-}}$ $\mathrm{H}_{5}$ in guaiacyl units (G). A signal at 123.920/7.342 ppm is associated with ferulate groups (FA). However, no signal is observed in the region from $60 \mathrm{ppm}$ to $100 \mathrm{ppm}$, which is generally associated with polysaccharides.

As shown in Fig. 13, the signals at 56.139/3.731 ppm, 104.508/ 6.794 ppm, 104.508/6.794 ppm, 116.155/6.860 ppm, 123.920/ $7.342 \mathrm{ppm}, 130.714 / 7.498 \mathrm{ppm}, 136.376 / 7.746 \mathrm{ppm}$, and 149.965/ $8.594 \mathrm{ppm}$ are associated with bamboo lignin. The signal at $56.139 / 3.731 \mathrm{ppm}$ is from methoxyl groups (MeO) in the aliphatic region. ${ }^{38}$ A signal at 104.508/6.794 ppm is associated with $\mathrm{C}_{2 / 6}$ $\mathrm{H}_{2 / 6}$ in etherified syringyl units (S). The signal at 116.155/ $6.860 \mathrm{ppm}$ is from guaiacyl units (G). A signal at 123.920/ $7.342 \mathrm{ppm}$ is associated with ferulate groups (FA). ${ }^{39} \mathrm{~A}$ signal at $130.662 / 7.509 \mathrm{ppm}$ is associated with p-coumarate groups (PCA).

\section{Conclusions}

In this study, ionic liquids were prepared via one-step synthesis as compared to other ILs reported in literature that required a two-step synthesis route. These ILs worked efficiently at a relatively low temperature of $90^{\circ} \mathrm{C}$ and $100{ }^{\circ} \mathrm{C}$ and a short processing time of $30 \mathrm{~min}$ for the pretreatment of lignocellulosic biomass.

These ionic liquids appeared to be more efficient at disruption of inter- and intra-molecular hydrogen bonding in the biopolymers comprising these biomasses. Ionic liquids interact with and solvate the aromatic moieties of lignin through $\pi-\pi$ and $n-\pi$ interactions between the aromatic rings and the cations of the IL. Lignin extraction yields of $61.0 \%$ and $60.4 \%$ from poplar were achieved with [Hnmp]Cl and $[\mathrm{Hmim}] \mathrm{Cl}$ pretreatments, respectively. Lignin extraction yields of $51.7 \%$ and $50.3 \%$ from bamboo were obtained with $[\mathrm{Hpy}] \mathrm{Cl}$ and [Hmim]Cl pretreatments, respectively.

The significantly decreased lignin content resulted in the high enzyme digestibility of cellulose. Additionally, the significant structural changes in morphology increased the accessibility of cellulase and then improved the enzymatic efficiency. The original fibrous structure was significantly disorder by ILpretreatment, which released a large area on the fiber surface, consequently improving the accessibility of cellulose and the enzymatic efficiency. Poplar with [Hpy]Cl pretreatment resulted in $67.5 \%$ glucose, $4.2 \%$ cellobiose and $10.4 \%$ xylose. Bamboo with $[\mathrm{Hmim}] \mathrm{Cl}$ pretreatment resulted in $65.5 \%$ glucose, $7.1 \%$ cellobiose and $11.8 \%$ xylose after enzymatic hydrolysis.

$[\mathrm{Hnmp}] \mathrm{Cl},[\mathrm{Hpy}] \mathrm{Cl}$, and $[\mathrm{Hmim}] \mathrm{Cl}$ were found to be very effective at lignin extraction and enzymatic saccharification for lignocellulosic biomass.

\section{Supplementary data}

\section{Pyridinium chloride ([Hpy]Cl)}

${ }^{1} \mathrm{H}-\mathrm{NMR}$ (400 MHz, DMSO-d ${ }_{6}$ ) (ppm): 8.135 (t, 2H, pyridinium ring), $8.684(\mathrm{t}, 1 \mathrm{H}$, pyridinium ring), $9.019(\mathrm{~d}, 2 \mathrm{H}$, pyridinium ring), and $12.357(\mathrm{~s}, 1 \mathrm{H}, \mathrm{N}-\mathrm{H})$.

${ }^{13} \mathrm{C}-\mathrm{NMR}$ (400 MHz, DMSO-d ${ }_{6}$ (ppm): 127.657 (s, 2C, pyridinium ring), 141.222 (s, 2C, pyridinium ring), and 146.803 (s, 1C, pyridinium ring). 
$\mathrm{N}$-Methyl-2-pyrrolidonium chloride ([Hnmp]Cl)

${ }^{1} \mathrm{H}-\mathrm{NMR}$ (400 MHz, DMSO-d ${ }_{6}$ ) (ppm): 1.831 (q, 2H, pyrrolidonium ring), 2.147 (t, 2H, pyrrolidonium ring), $2.633\left(\mathrm{~s}, 3 \mathrm{H},-\mathrm{CH}_{3}\right)$, $3.255(\mathrm{t}, 2 \mathrm{H}$, pyrrolidonium ring), and $13.511(\mathrm{~s}, 1 \mathrm{H}, \mathrm{N}-\mathrm{H})$.

${ }^{13} \mathrm{C}-\mathrm{NMR}$ (400 MHz, DMSO-d $\mathrm{d}_{6}$ ) (ppm): 17.582 (s, 1C, pyrrolidonium ring), 29.530 (s, 1C, $-\mathrm{CH}_{3}$ ), 30.463 (s, 1C, pyrrolidonium ring), 49.153 (s, 1C, pyrrolidonium ring), and 174.474 (s, 1C, pyrrolidonium ring).

\section{1-H-3-Methylimidazolium chloride ([Hmim]Cl)}

${ }^{1} \mathrm{H}-\mathrm{NMR}$ (400 MHz, DMSO-d ${ }_{6}$ ) (ppm): 2.079 (f, $2 \mathrm{H},-\mathrm{CH}_{2}-$ ), 2.444 $\left(\mathrm{t}, 2 \mathrm{H},-\mathrm{CH}_{2}-\right), 3.841\left(\mathrm{~s}, 3 \mathrm{H},-\mathrm{CH}_{3}\right), 4.290\left(\mathrm{t}, 2 \mathrm{H},-\mathrm{CH}_{2}-\right), 7.704(\mathrm{~s}$, $1 \mathrm{H}$, imidazolium ring), $7.779(\mathrm{~s}, 1 \mathrm{H}$, imidazolium ring), and 9.159 (s, 1H, imidazolium ring).

${ }^{13} \mathrm{C}-\mathrm{NMR}$ (400 MHz, DMSO-d ${ }_{6}$ (ppm): 26.050 (s, $1 \mathrm{C},-\mathrm{CH}_{2}-$ ), 35.677 (s, $1 \mathrm{C},-\mathrm{CH}_{3}$ ), 47.309 (s, $1 \mathrm{C},-\mathrm{CH}_{2}-$ ), 47.666 (s, $1 \mathrm{C},-\mathrm{CH}_{2}-$ ), 122.246 (s, 1C, imidazolium ring), 123.538 (s, 1C, imidazolium ring), and 136.710 (s, 1C, imidazolium ring).

\section{Conflicts of interest}

There are no conflicts to declare.

\section{Acknowledgements}

This work was financially supported by the National Natural Science Foundation of China (21506030).

\section{References}

1 S. Siankevich, Z. Fei, N. Yan and P. J. Dyson, Chimia, 2015, 69, 592-596.

2 L. Petrus and M. A. Noordermeer, Green Chem., 2007, 38, 861-867.

3 S. H. Lee, T. V. Doherty, R. J. Linhardt and J. S. Dordick, Biotechnol. Bioeng., 2009, 102, 1368-1376.

4 N. I. Haykir, E. Bahcegul, N. Bicak and U. Bakir, Ind. Crops Prod., 2013, 41, 430-436.

5 T. Heinze, K. Schwikal and S. Barthel, Macromol. Biosci., 2005, 5, 520-525.

6 Y. Dong, J. Holm, J. Kärkkäinen, J. Nowicki and U. Lassi, Biomass. Bioenerg., 2014, 70, 461-467.

7 D. Fu, G. Mazza and Y. Tamaki, J. Agric. Food Chem., 2010, 58, 2915-2992.

8 L. Wei, K. Li, Y. Ma and X. Hou, Ind. Crops Prod., 2012, 37, 227-234.

9 Q. Li, Y. C. He, M. Xian, G. Jun, X. Xu, J. M. Yang and L. Z. Li, Bioresour. Technol., 2009, 100, 3570-3575.

10 K. Ninomiya, K. Inoue, Y. Aomori, A. Ohnishi, C. Ogino, N. Shimizu and K. Takahashi, Chem. Eng. J., 2015, 259, 323-329.

11 C. Li, B. Knierim, C. Manisseri, R. Arora, H. V. Scheller, M. Auer, K. P. Vogel, B. A. Simmons and S. Singh, Bioresour. Technol., 2010, 101, 4900-4906.

12 D. Yang, L. X. Zhong, T. Q. Yuan, X. W. Peng and R. C. Sun, Ind. Crops Prod., 2013, 43, 141-149.
13 J. Y. Kim, E. J. Shin, I. Y. Eom, K. Won, Y. H. Kim, D. Choi, I. G. Chio and J. W. Choi, Bioresour. Technol., 2011, 102, 9020-9025.

14 J. K. Xu, Y. C. Sun and R. C. Sun, Process Biochem., 2015, 50, 955-965.

15 A. D. Sluiter, B. Hames, R. Ruiz, C. Scarlata, J. Sluiter, D. W. Templeton and D. Crocker, NREL/TP-510-42618, National Renewable Energy Laboratory, Golden, CO, 2012.

16 B. X. Zhang, Y. F. Wang and X. M. Hu, Ind. Crops Prod., 2015, 76, 688-696.

17 L. C. Segal, J. J. Creely, A. E. J. Martin and C. M. Conrad, Text. Res. J., 1959, 29, 786-794.

18 G. Cheng, P. Varanasi, C. Li, H. Liu, Y. B. Melnichenko, B. A. Simmons, M. Kent and S. Singh, Biomacromolecules, 2011, 12, 933-941.

19 G. L. Miller, Anal. Chem., 1959, 31, 175-201.

20 N. Sun, H. Liu, N. Sathitsuksanoh, V. Stavila, M. Sawant, A. Bonito, K. Tran, A. George, K. L. Sale, S. Singh, B. A. Simmons and B. A. Holmes, Biotechnol. Biofuels, 2013, 6, 39-52.

21 N. Sun, M. Rahman, Y. Qin, M. L. Maxim, H. Rodríguez and R. D. Rogers, Green Chem., 2009, 11, 646-655.

22 X. Wang, H. Li, Y. Cao and Q. Tang, Bioresour. Technol., 2011, 102, 7959-7965.

23 H. T. Vo, C. S. Kim, B. S. Ahn, H. S. Kim and H. Lee, J. Wood Chem. Technol., 2011, 31, 89-102.

24 J. Xu, B. Wu, L. Hu, Z. Wu, N. Xu, B. L. Dai and J. He, Chem. Eng. J., 2015, 267, 163-169.

25 D. A. Fort, R. C. Remsing, R. P. Swatloski, P. Moyna, G. Moyna and R. D. Rogers, Green Chem., 2007, 9, 63-69.

26 M. Lawoko, G. Henriksson and G. Gellerstedt, Holzforschung, 2006, 21, 143-165.

27 H. Wu, M. Mora-Pale, J. Miao, T. V. Doherty, R. J. Linhardt and J. S. Dordick, Biotechnol. Bioeng., 2011, 108, 2865-2875.

28 D. Fu and G. Mazza, Bioresour. Technol., 2011, 102, 7008-7011.

29 A. Pinkert, D. Goeke, K. N. Marsh and S. Pang, Green Chem., 2011, 13, 3124-3136.

30 X. Pan, D. Xie, N. Gilkes, D. J. Gregg and J. N. Saddler, Appl. Biochem. Biotechnol., 2005, 124, 1069-1079.

31 A. W. King, J. Asikkala, I. Mutikainen, P. Järvi and I. Kilpeläinen, Angew. Chem., Int. Ed., 2011, 50, 6301-6305.

32 A. Casas, M. V. Alonso, M. Oliet, E. Rojo and F. Rodriguez, J. Chem. Technol. Biotechnol., 2012, 87, 472-480.

33 W. Lan, C. F. Liu, F. Yue, R. C. Sun and J. F. Kennedy, Carbohydr. Polym., 2011, 86, 672-677.

34 X. Chen, Y. Gao, L. Wang, H. Chen and N. Yan, ChemPlusChem, 2015, 80, 1565-1572.

35 W. Xiao, W. Yin, S. Xia and P. Ma, Carbohydr. Polym., 2012, 87, 2019-2023.

36 L. Wu, A. Kumagai, S. H. Lee and T. Endo, Bioresour. Technol., 2014, 162, 207-212.

37 A. Alemdar and M. Sain, Bioresour. Technol., 2008, 99, 16641671.

38 T. Q. Yuan, T. You, W. Wang, F. Xu and R. C. Sun, Bioresour. Technol., 2013, 136, 345-350.

39 A. M. Socha, S. P. Plummer, V. Stavila, B. A. Simmons and S. Singh, Biotechnol. Biofuels, 2013, 6, 61-70. 